
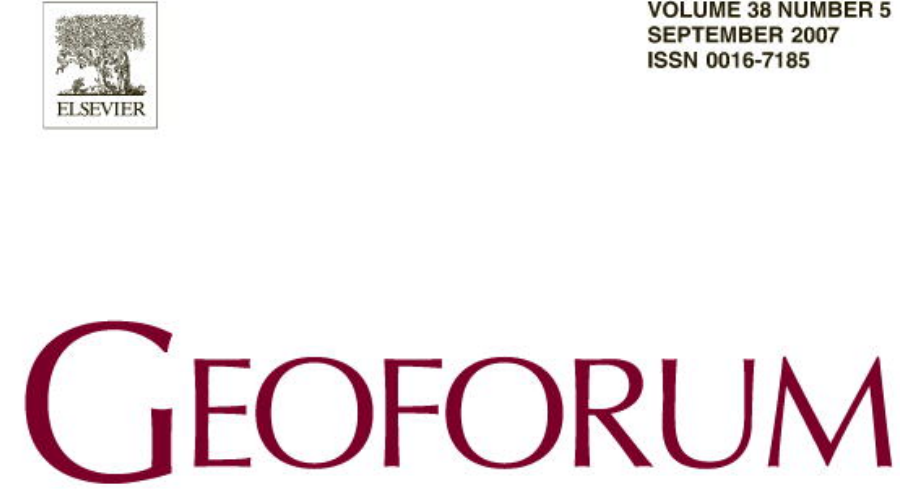

EDITORS

Katie Willis

Paul Robbins

Michael Samers

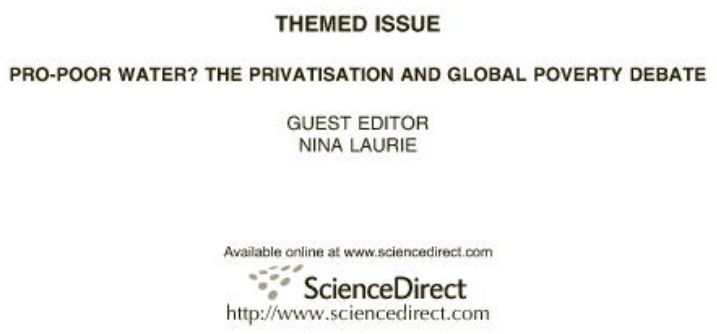

This article was published in an Elsevier journal. The attached copy

is furnished to the author for non-commercial research and education use, including for instruction at the author's institution, sharing with colleagues and providing to institution administration.

Other uses, including reproduction and distribution, or selling or licensing copies, or posting to personal, institutional or third party websites are prohibited.

In most cases authors are permitted to post their version of the article (e.g. in Word or Tex form) to their personal website or institutional repository. Authors requiring further information regarding Elsevier's archiving and manuscript policies are encouraged to visit: 


\title{
Good governance in the Pacific? Ambivalence and possibility
}

\author{
Susan M. Roberts ${ }^{\mathrm{a}, *}$, Sarah Wright ${ }^{\mathrm{b}}$, Phillip O’Neill ${ }^{\mathrm{c}}$ \\ a Department of Geography, University of Kentucky, Lexington, KY 40506-0027, USA \\ ${ }^{\mathrm{b}}$ Centre for Urban and Regional Studies, University of Newcastle, Callaghan, NSW 2308, Australia \\ ${ }^{\mathrm{c}}$ Urban Research Centre, University of Western Sydney, Penrith South, NSW 1797, Australia
}

Received 14 September 2006; received in revised form 9 April 2007

\begin{abstract}
In September 2005, the Pacific Islands Forum issued a finalized Pacific Plan. The overarching goal of the Plan is to "Enhance and stimulate economic growth, sustainable development, good governance and security for Pacific countries through regionalism." In this paper we focus on the salient role of (good) governance in the Plan. Governance has become a keyword, albeit a deeply ambivalent one, in development and foreign policy realms and the Pacific is now a particularly intense site of activities understood in terms of governance. Governance has become an important vehicle through which intervention in the region is imagined and realized.

Using interviews with persons connected in various ways with the development of the Pacific Plan and from a documentary history, we address questions about the political closures and openings enabled by the governance agenda. We investigate the kinds of work that gets done in the name of governance through an analysis of the ways that it is understood, deployed and redefined in practice. To do this we turn to the Pacific Plan as our case. We find that governance, as it is defined and operationalized in the Plan, is pulled in a highly technocratic direction such that a particularly narrow conceptualization of governance dominates. Despite this disciplining process, however, the continued salience of governance as a framing device within struggles for racial and gender equality and the emergence of Pacific-based projects that act to remake governance in unexpected ways leads us to conclude that the term retains fields of meaning that allow for alternative political openings and possibilities.
\end{abstract}

(C) 2007 Elsevier Ltd. All rights reserved.

Keywords: Pacific; Pacific Islands Forum; Pacific Plan; Governance; Good governance; Development

\section{Introduction}

"Bad governance is being increasingly regarded as one of the root causes of all evil within our societies." (UN Economic and Social Commission for Asia and the Pacific, n.d.)

"'Good governance' is a serious contender for a prize for the best example of Orwellian doublespeak." (Choudry, 2002)

Governance has become a 'keyword' (Williams, 1985) within development and foreign policy circles. Pressing

\footnotetext{
${ }^{*}$ Corresponding author.

E-mail addresses: sueroberts@uky.edu (S.M. Roberts), sarah.wright@newcastle.edu.au (S. Wright), p.oneill@uws.edu.au (P. O’Neill).
}

problems faced by billions of people are increasingly understood in terms of 'bad' or 'poor' governance. Though rarely precisely defined, bad governance signals practices such as corruption, manipulation of the media, disrespect for human rights, arbitrary application of the rule of law, actual or potential political instability and the like, most often defined as 'lacks' (Doty, 1996) - lack of accountability, lack of transparency, and so on. Good governance, for which there are many competing definitions, signals 'presences' - of the rule of law, of stability, of financial transparency, accountable state officials, of human rights, of a free media. Good governance is often paired with 'democracy,' another keyword in the contemporary lexicon, and while the opprobrium attached to bad governance is directed most often at the state, good governance is assumed to involve not only a reformed state but also civil society and 
capital (Swyngedouw, 2005). The problems of troubled regions, such as sub-Saharan Africa or the Pacific islands, once framed almost entirely as economic, are now diagnosed first and foremost as political, with poverty seen as resulting from bad governance, making governance the thing that has to be fixed first in any attempt to ensure economic development (Leftwich, 1993, 1994, 2005; Macdonald, 1995).

Governance has become a central tenet, not just of the imagined geographies of the world - huge swathes painted in a color indicating 'bad governance' conjured up by wellknown mappings such as those by Freedom House (2005a) - but also of macro- and micro-practices of development. Governance has become an agenda and a set of practices, riddling the worlds of development and foreign policy, from the loftiest pronouncements of powerful statesmen and women to the log frames that field officers working for development non-governmental organizations (NGOs) must complete to assess their projects in this or that village. Governance is now a recurring and deeply unsettled figure within international policy discourse, and one with considerable force - both symbolic and material.

Given that the governance agenda brings political issues to the fore in considerations of development, those of us who count ourselves as political economists or who are sympathetic to approaches that consider both economic and political dynamics, might greet governance as a welcome break with the dominant economism of many theoretical and applied understandings of the situations facing people in the world's poorer countries (Fine, 2002). We might hope the many reports, policy documents, research papers and so on considering the issue of governance would create opportunities for serious consideration of the politics of development (not just politics and development). We might find hopeful this renewed attention to politics as it appears to open up the possibility for debate and practice regarding distributive issues and suggests a new entry point for efforts to change processes of social inequality and exclusion. Because governance in this optimistic reading is about politics with a small 'p' and its outcome is not necessarily predetermined (it might not propose that western-style representative democracy or neoliberal capitalism are the only possible results, for example), the term may be regarded as having an openness or even an unruliness about it (Hewitt de Alcántara, 1998; Gibson-Graham, 2006). Moreover, even if the governance agenda fails to promote radical political possibilities, it may direct attention to issues, such as human rights abuses, discriminatory application of the law, and corruption, that negatively impact the lives of millions.

On the other hand, we could be somewhat suspicious of a new prominence for the term governance. Its slipperiness may be taken as a sign of its potentially arbitrary application by aid donors and development actors who cite the need to be selective in allocating aid as they redirect aid flows to conform to the strategic objectives in the present 'war on terror' (Hout, 2004; Jayasuriya and Hewison,
2004). Indeed, the governance agenda has meshed fairly seamlessly with the increased emphasis on security issues generating a certain skepticism about the geopolitical instrumentality of the term (Duffield, 2001; Nederveen-Pieterse, 2004). Simply noting that governance has been enthusiastically taken up by the world's major international financial institutions, biggest donor countries and development organizations, we might write it off as just the latest example of a term being pressed into service by hegemonic institutions, going the way of 'sustainability' and 'participation' before it (Walker et al., 2007). We might assume that the term governance, as it is put to work in the name of development, would be evacuated of critical political content, tamed and harnessed to help make the world safer for citizens of the global 'west' and for transnationalizing capital (Jayasuriya and Hewison, 2004).

Or is it possible that the term governance could contain both these stories? Is it an idea that is still very much contested and negotiated, always being reworked as it is put into practice? Might it be more properly understood as ambivalent (Fairclough, 1991) rather than as ambiguous or vague, drawing discursive strength and lifespan from a capacity to contain different, even contradictory, definitions? Does the term thus invite interpretation in several distinct ways, and could it be simultaneously and variously of instrumental value to hegemonic development institutions, to elements of the state and to grassroots groups of citizens working for social change?

To begin to address such questions, we need to ask about the kinds of work that gets done in the name of governance and move to an examination of the workings of specific instances of the governance agenda in practice. In this paper we therefore offer an analysis of the ways governance is understood, deployed and redefined in practice. To do this, we turn to the Pacific. The region is posited as part of an 'arc of instability' (Connell, 2006; Duncan and Chand, 2002); its economies vulnerable, its future insecure. Both its problems and their solutions are now routinely characterized in terms of governance and major institutions active in the region have taken up the governance agenda with gusto. The key international institutional grouping in the Pacific at the present is the Pacific Islands Forum (PIF). We build our analysis of governance in the Pacific empirically, through a focus on the way that governance has been conceptualized and operationalized by the Forum in its key regional planning document: the Pacific Plan.

The Pacific Islands Forum was founded as the South Pacific Forum in 1971. Since then, it has expanded its membership and power to become the major institutional site for the negotiation and implementation of regional agreements (for example on fishing). Over the past decade the Forum has become an increasingly significant institution in the region, enjoying ramped-up support from its two richest members - Australia and New Zealand - plus increased funding from the European Union and Japan, and major international financial institutions (Doran, 2004; Sutherland, 2000). 
In April 2004, leaders of the 15 PIF member countries met and issued the Auckland Declaration. ${ }^{1}$ This brief 700 word statement laid out the leaders' vision for their region and its population of over 30 million people, and called for the vision's realization through a regional plan. Less than two years later, in September 2005, the finalized Pacific Plan appeared. The Plan calls for "strengthening regional cooperation and integration" to bring about greater efficiencies in service provision and to facilitate intra-regional trade (PIF, 2005a). With only three PIF member countries having populations greater than one million (Australia, New Zealand, and Papua New Guinea), regionalism is seen first and foremost as a way for small countries to realize economies of scale (see Rolfe, 2006, for a critique of this logic). In the Plan, this rather straightforward economic rationale is assumed to be unworkable without significant improvements in governance throughout the region (O'Neill et al., 2006). In formulating and agreeing to the Plan, Pacific islands' leaders committed themselves and the people they represent to abide by a set of principles of 'good governance' deemed necessary to ensure the benefits of regionalism.

As we investigate the keyword, governance, we look to how it was incorporated into the Plan, the ways that it is defined within the Plan, and the processes whereby it is to be implemented and monitored. We find that the politically unruly and quite radical attributes of the idea have been largely foreclosed. Governance, as presented in the Plan, is tamed, limited to the building of particular kinds of institutions that focus on rendering the economies of the Pacific recognizable to and disciplined for transnational capital, with a heavy emphasis on neoliberal prescriptions (such as diminished public sectors, expanded and secured property rights and the guarantee of enforceable contracts) and on security fixations. In terms of monitoring, the idea of good governance is further narrowed by its reliance on six World Bank indicators that purport to know (and so reinvent) the Pacific and its ways of governing. We find the Pacific re-read and re-made through these indicators, formulated and calculated in the centers of western power as they bring to bear a technocentric, neoliberal and securitized vision of good governance on the peoples of the Pacific (cf. Hewitt de Alcántara, 1998). Furthermore, governance frames problems in the Pacific in a way that invites - even demands - intervention. It works to redirect criticism away from more structural or historical approaches that might consider the ways in which the Pacific islands are already unequally, unevenly, or perhaps overly, enmeshed in globalizing capitalist relations. Further, this tamed notion of governance also leaves the development industry itself outside the framing of the problem by focusing attention on the 'lacks' of national institutions (and their leaders and officials). The Pacific Plan, then, in its

\footnotetext{
${ }^{1}$ The members of the PIF whose leaders met in Auckland were: Australia, the Cook Islands, Federated States of Micronesia, Fiji, Kiribati, New Zealand, Niue, Palau, Papua New Guinea, Republic of the Marshall Islands, Samoa, Solomon Islands, Tonga, Tuvalu and Vanuatu.
}

appropriation and promulgation of a particular type of governance works against the kind of open politics the term can also signal.

However, despite the overall emphases on institutionbuilding and government, and despite an evident technocratic drift (in the sense of a strong directional 'pull'; see Morgan, 2006 on technocratic accountability) at work in the Plan, the term refuses total confinement. In our analysis, we find instances when the term's ambivalence seems to permit room for maneuver, and thus for progressive, even radical politics. Interviews with people active in civil society groups in the Pacific and investigations of civil society practices around governance reveal scope for action within and beyond the remit of the Plan; action that imbues the idea of governance in the Pacific with different meanings, redirecting the technocratic emphases. ${ }^{2}$ Civil society groups not only mobilize the term to advance agendas associated with, for example, transparent decision making processes, human rights, equality before the law and gender issues, but work to remake the idea of governance through programs that attempt to build upon the diverse and differently situated aspirations of Pacific peoples. We conclude cautiously that the governance agenda, while it is being driven from above through the Pacific Islands Forum, may not be entirely nor inevitably pernicious when it comes to imagining and making Pacific futures in which ordinary people enjoy rights, justice and economic security.

\section{Governance}

While a deep history of the concepts of governance and good governance would trace their origins through the enlightenment and western liberalism, their more immediate roots are in late twentieth century development theory and practice (Pagden, 1998; Zanotti, 2005). Modernization theory and subsequent development orthodoxies focused on economic dynamics, albeit moderated by attention to basic needs, sustainability and so on and it wasn't until the late 1980s and 1990s that governance per se came into vogue in development circles, with explicit attention given to the significance of political institutions and processes.

Martin Doornbos, in looking back at the appearance of good governance on the development agenda, remarked:

... it has been striking to see how in virtually no time the term 'governance', retrieved from a lingering, obscure existence, became a household word figuring on the tops of the list of concerns of aid agencies, governments, researchers and the media. (2001, p. 94)

Writing in 1994, David Williams and Tom Young observed "Good government and governance have become almost an obsession in current debates about development" (1994, p. 84) and five years later Imtiaz Ahmed noted that

\footnotetext{
${ }^{2}$ Interviews with a number of persons involved in the Pacific Islands Forum, civil society groups and development agencies were conducted in February 2006 in Suva, Fiji.
} 
governance had become a "compulsion" (Ahmed, 1999, p. 295). The turn to governance by the World Bank, and then by most other international and national development agencies, was very much an extension of neoliberal principles. Markets require minimalist states, according to neoliberal reasoning, and thus in the 1980s and 1990s there was an emphasis on 'public sector reform' which meant transitioning to a leaner type of state structure, the shedding of state-held assets through privatization, and the slimming of civil service ranks. Importantly, such reforms were already 'road-tested' in the transition of formerly socialist countries in the early 1990s and had also been part and parcel of conditionalities imposed on so-called developing economies, including those of the Pacific, by the IMF and other lenders (Larmour, 2002; Sutherland, 2000).

The World Bank was the key institution that formulated, adopted and promoted the governance agenda early on (Doornbos, 2001; Williams and Young, 1994). Its 1989 report on Sub-Saharan Africa diagnosed the crisis in that region as a "crisis in governance" (Williams and Young, 1994). Sub-Saharan Africa's development problems continue to be framed in terms of governance; specifically, the purported lack of 'good' governance (Abrahamsen, 2000; Fallah, 2006).

In 1992 the World Bank's report Governance and Development generalized the points that had previously been made with respect to Africa. The term then cascaded through the major international development agencies, being taken up as a central theme by the Asian Development Bank (ADB) in 1995, the International Monetary Fund (IMF) in its Code of Good Practices on Fiscal Transparency in 1996, the United Nations Development Program (UNDP) in 1997, and by major bilateral donors such as Great Britain's DFID and the United States' USAID (Zanotti, 2005). The Asian Financial Crisis of 1997 served to further impel the uptake of the governance agenda, especially in Asia (Thompson, 2004).

The UNDP began its first project explicitly focused on governance in the Pacific in 1994, carried out jointly with the Forum (UNDP, 2005, p. 47). Under this program, the UNDP offered technical assistance to Forum members on matters such as legislative reform. That program was expanded in 2001, becoming the Governance for Livelihoods and Development in the Pacific (GOLD) program and focusing on: accountability and transparency; judicial training and reform; parliamentary support and capacity building; and human rights advocacy and institutional support (UNDP, 2005, pp. 47-48). For the UNDP,

Good governance is the equal participation of all citizens in decision-making. Good governance is transparent, accountable, equitable and promotes the rule of law. It allows the poor and the most affected to be heard when decisions are made and resources are handed out. It is governance that is owned and shaped by the people. (UNDP, 2005)
The Forum, it turns out, has not proven so attached to the people-centered approach championed by the UNDP.

The Forum built its own specific meaning of governance, adopting in 1997 the "Eight Principles of Public Accountability" (often referred to in PIF documents as "Eight Principles of Good Governance" (e.g., PIF, 2000a)). Later, in October 2000, Forum leaders issued the Biketawa Declaration which laid out principles regarding regional action in cases of serious instability in a member state, the first of which was "Commitment to good gover-

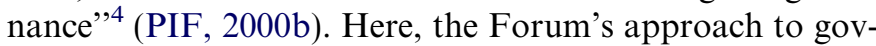
ernance moved from a technocratic and institutional (1997) iteration to one in which governance is paired closely with security. This shift coincided with Australia's moves to modify the Forum's previously held commitment to a principle of non-interference in one another's affairs (see below).

In addition to the Forum's uptake of governance, it seems that every development institution active in the Pacific has an on-going governance program - either of its own or now allied with the efforts underway as part of the Pacific Plan. Indeed, the UNDP counts at least 12 other major organizations actively involved in promoting good governance in the Pacific (UNDP, 2005, pp. 50-52). For many of the agents of this agenda, the term is narrowly focused. For example, The World Bank's approach has aligned with the "anti-corruption crusade" (Brown and Cloke, 2004; Larmour, 1997) and a basic focus on "building the climate for investment" (see Wolfowitz, 2006; World Bank, 2005a). The UNDP's people-centered approach has been sidelined by a governance agenda focused on business-friendly financial and economic management (UNDP, 2005, p. 49; Choudry, 2002).

Even while the governance agenda has become more narrowly technocratic, it remains slippery. Doornbos com-

\footnotetext{
${ }^{3}$ The Eight Principles of Accountability adopted by the Forum Economic Ministers Meeting were: (1) Budgetary processes, including multi-year frameworks, to ensure that Parliament/Congress is sufficiently informed to understand the longer-term implications of appropriation decisions. (2) The accounts of governments, state-owned enterprises and statutory corporations to be promptly and fully audited, and the audit reports published where they can be read by the general public. (3) Loan agreements or guarantees entered into by governments to be presented to Parliament/Congress, with sufficient information to enable Parliament/ Congress to understand the longer-term implications. (4) All government and public sector contracts to be openly advertised, competitively awarded and administered, and publicly reported. (5) Contravention of financial regulations to be promptly disciplined. (6) Public Accounts/Expenditure Committees of Parliament/Congress to be empowered to require disclosure. (7) Auditor General and Ombudsman to be provided with adequate fiscal resources and independent reporting rights to Parliament/Congress. (8) Central Bank with statutory responsibility for nonpartisan monitoring and advice, and regular and independent publication of informative reports. (PIF, 1997)

${ }^{4}$ In full: "Commitment to good governance which is the exercise of authority (leadership) and interactions in a manner that is open, transparent, accountable, participatory, consultative and decisive but fair and equitable." (PIF, 2000b)
} 
plains that "an elastic term like governance, rather than constituting a concept in its own right, is more like a flexible carrier which can be used to convey varying combinations of messages and consignments..." and so it seems in the Pacific (Doornbos, 2001, p. 95). As Merilee Grindle has noted, governance has tended to be an expansive term, denoting an ever longer list of policy prescriptions (Grindle, 2002, pp. 11-12). Under the present 'war on terror' and the associated emphasis on security of various types, the governance agenda has expanded in that direction and, in the process, has been re-invigorated (cf. Moore, 2002). Geopolitically, the frequent invocation of poor, bad, or weak governance to diagnose the ills of poorer countries is allied to an increased emphasis on corruption (Brown and Cloke, 2004) and draws meaning from related descriptors such as 'failed' or 'failing states', and 'fragile states' (Leftwich, 2005). Such terms are now "widely deployed to identify parts of the world outside the congress of global liberalism, states whose failures must be corrected if the global jigsaw puzzle of liberal democracy is to be completed" (Smith, 2005, p. 194). Post 9/11, war on terror geopolitical constructions of regions as potential sites for fomenting terrorism become part of the reason why the governance agenda in the Pacific receives support from foreign policy interests in relatively powerful countries such as the US and Australia. These constructions also influence foreign aid directions. We could say that in the present geopolitical era there is an intensification in the application of the security-governance nexus in certain regions or zones, including the Pacific (see Ong, 2006, on governance and zoning more generally).

With the gaze of governance turned upon the Pacific, the region is once more (re)imagined as lacking, framed in a way that suggests the need for foreign intervention. The particular modes of governance adopted and used in the Pacific are firmly embedded in a liberal and western way of seeing and doing, with strong links to the neoliberal project and to a fixation on security. Importantly, the governance agenda is being applied to/in the Pacific by major donors and development institutions with scant regard for indigenous ways of understanding and practicing governance (Huffer, 2005; Huffer and So'o, 2005) in ways redolent of other moments in the long western project of modernity/development (Mitchell, 2002). Through good governance, the Pacific, for reasons peculiar to its history and geopolitical position, has become a particularly intense arena for these efforts.

\section{The Pacific}

The Pacific Islands have long been characterized as loci of instability and economic backwardness that demand intervention. Within colonial discourses, the Pacific Islands and Pacific Islanders have been represented in contradictory ways. At times childlike, passive, warlike, savage, sexualized and innocent, a common thread linking these characterizations is that they legitimize intervention that promises, variously, civilization, economic advancement, modernity and redemption (Thomas, 1992). During the Cold War, representations of the region tended towards portrayals of peoples vulnerable to outside pressure, naïve and easily led (Fry, 1997). The economic and political problems facing the islands made them ripe for "undesirable external interference" (Payne, 1993, p. 109). The Pacific Islands continue to be depicted as volatile and somehow untrustworthy, particularly in contrast to a Europeanbased knowability of Australia and New Zealand (Greener-Barcham and Barcham, 2006). In its most recent manifestation, the 'tropicality' (Rajaram, 2003) of the region, its unpredictability and strangeness, is constituted through its incorporation into an 'arc of instability' that stretches through Indonesia, East Timor, Papua New Guinea, the Philippines to Melanesia (e.g., Connell, 2006; Duncan and Chand, 2002; Rumley et al., 2006). As potential and actual sites of civil unrest and conflict, countries and political movements in this arc are scripted as a "terrorist's paradise" (Harvey, 2004); places in which, and from which, terrorist attacks, according to Australia's Prime Minister John Howard, are "nearly inevitable" (Howard and Dobell, 2004).

Summarily, the region's economic future is posited as unremittingly bleak. With their stubborn inability to cultivate economic growth exacerbated by small size and isolation, dramatically increasing populations, skills shortages plus extant and looming environmental devastation, the island economies are represented as deeply troubled and practically unmanageable (Fry, 1997; Murray and Storey, 2003). The islands' economic prognosis, at least according to sources such as the World Bank, bilateral agencies and the foreign media, is as alarming as it is dismal. Together, high unemployment, cumbersome communal property systems, corruption and inefficiency combined with health and environmental challenges and a slow pace of reforms paint a picture of a region that is in danger of collapse (Barlow, 2006).

The joint themes of security threats and economic unmanageability interweave with discourses of development associated with the Pacific. The lack of economic growth creates a potential breeding ground for dissent, while conflict impedes economic reforms and potentially sets up a domino effect across other islands in the arc threatening the integrity of Australia and New Zealand. It is this unmanageability and vulnerability that is posited as the basis for aid and intervention in the region. In the contemporary political situation, the appropriate response to such instability, unknowability and economic intractability is seen as coming from outside the islands themselves. Increasingly it is rendered in terms of the good governance agenda delivered through, and as a condition of, aid.

Aid has played an important role in the Pacific in recent decades and the region is often depicted as aid dependent. Aid is seen as at once the salvation and the downfall of island economies. Major players include those with a past and/or continuing colonial presence in the region such as 
Britain, France and the USA; ' $^{5}$ the region's 'big brothers' Japan, Australia and New Zealand; and multilateral development organizations such as, the World Bank and the ADB. Aid flows to the Pacific islands are often enmeshed in the politics of access to resources. Access to the region's fisheries, in particular, has been exchanged for aid (Petersen, 2003). For the region, bilateral aid dominates aid flows, making up 95\% of all aid (World Bank, 2005b). Despite the lack of demonstrable successes in terms of economic development, aid flows to the region are increasing. Australia is expanding its aid program in the region. In 2006-2007 it increased its overall budget by $15.5 \%$. Of particular interest is that more of a third of Australia's aid budget is now delivered through governance programs (Ausaid, 2006a,b).

That the region continues to struggle economically despite high levels of foreign aid is itself seen as further evidence that drastic change is needed (Huffer and Molisa, 1999). The "Pacific paradox," a term coined by the World Bank in an influential 1993 report, purported to capture the situation wherein countries receiving significant aid per capita, employing largely "appropriate" economic management, and having a strong human and environmental resource bases could still show such slow growth in per capita income (Sutherland, 2000). Over 10 years later, the paradox, for bilateral and multilateral aid agencies at least, has been explained. No longer recognized as having "generally sound economic management" (World Bank, 1993, quoted in Sutherland 2000, p. 459), the region is now seen as in need of drastic reform in political and economic management. Good governance, in other words, has arrived on the scene as the solution for the "Pacific paradox".

In the case of the Pacific, two countries, Australia and New Zealand, by virtue of their substantially larger and more robust economies, are able to be simultaneously members of the region (and regional groupings such as the Pacific Islands Forum) and powerful actors exerting pressure on the poorer countries of the region. Australia plays an important role in the Pacific as a major aid donor and through direct intervention. ${ }^{6}$ As Rajaram (2003, p. 290) points out, "Australia is not entirely of the region but the region is Australia's; it is Australia's dependent backyard." Like a backyard, the Pacific is regarded, by Australia (supported by the $\mathrm{USA}^{7}$ ), as a place that needs to be watched over, tended and managed (Henningham, 1996). Managing the backyard means keeping it orderly,

\footnotetext{
5 Aid from France and the US remains heavily linked to those countries with which they had, or have, colonial links. The US provides general budget support to countries with which it has Compacts of Free Association, namely Micronesia, Marshall Islands and Palau, while France supplies high levels of aid to its territories.

${ }^{6}$ Including military intervention in the Solomon Islands and through offshore immigration processing centers in Nauru and Manus Island, Papua New Guinea.

${ }^{7}$ George Bush reportedly referred to Australia as his "sheriff" in the Pacific (Kremmer, 2003).
}

and in the contemporary era this is largely understood through the lens of the governance agenda.

Even militaristic interventions by Australia in the Pacific are represented in terms of governance (Greener-Barcham and Barcham, 2006). For example, the 2003 Australianled Regional Assistance Mission to Solomon Islands (RAMSI) was to "help the Solomon Islands Government restore law and order, strengthen government institutions, reduce corruption and re-invigorate the economy" (DFAT, n.d., a). Additionally, and often in the name of order and good governance, Australia's immigration policy has further demonstrated the asymmetrical geography of power in the region as Australia has used its "backyard" as a holding pen, diverting incoming asylum seekers to offshore detention centers in the Pacific and thus strengthening its privileged emplacement in/on the region through the manipulation and policing of borders (Green, 2004; Rajaram, 2003). For Australia, the future of the Pacific without Australia's (neoliberal and security-oriented) guidance can only be one of collapse - or, at best, according to the Australian government's Pacific 2020 report, one of "muddling on" (Agence France Presse, 2006).

New Zealand stands in a somewhat different relation to the region, and has been more qualified in its adoption of the governance agenda and associated interventionism (Henderson, 2003). However, both Australia and New Zealand manage, imagine and work to reconfigure the region through strategic accommodations with other rich countries with regional interests (such as Japan, see the Okinawa Partnership, (Kyodo News, 2006)), by taking central roles in such Pacific-based organizations as the Pacific Forum (see below) and through good governance projects (Goldsmith, 2005).

Australia and New Zealand's roles in the Pacific Islands Forum have long been characterized by certain tensions (Fickling, 2002). As countries with considerably more power, larger economies, more assertive foreign policies and as major funders of the Forum, the two countries have been alternately criticized for "snubbing" the Pacific (Asia Pulse, 2001) and for neo-colonial attitudes towards their neighbors (Baker, 2006). Along with the Cook Islands, Fiji, Nauru, Tonga and Western Samoa, Australia and New Zealand were founding members of the Pacific Islands Forum (DFAT, n.d., b). Until recently, however, their involvement has been relatively low key, or at least behind the scenes (Courier Mail, 2004). For example, in 1998, 1999, and 2001 the Australian Prime Minister did not attend the Forum Heads of Government meetings (Asia Pulse, 2001). With an increasing focus on security and the perceived need for intervention in the region, Australia stepped up its involvement from 2002 onwards. On the premise that there would be no more "free rides" in the Pacific (Urban, 2002), Prime Minister John Howard raised hackles with pronouncements that Australia would link future aid to conditionalities, particularly in the area of governance (Fickling, 2002; Grubel, 2003), and that an Australian, Greg Urwin, should be installed as the secretary general 
of the PIF (Fry, 2005). In a ministerial statement released as Howard left for a Forum leaders summit in Auckland in 2003, he announced, "Failed states can all too easily become safe-havens for transnational criminals and even terrorists ... We have made it plain - nations who look for our assistance, who receive our financial aid, must understand support is now conditional on working to overcome corruption" (Howard quoted in Grubel, 2003).

Six countries opposed the installment of an Australian secretary general calling instead, in line with usual practice, for a Pacific Islander to head the Forum (Davis, 2003). A vote was forced on the issue and Urwin was elected (Chin, 2003). Then in April 2004 Forum leaders met in Auckland and agreed to a "radical reform agenda" (Lilley, 2004) with governance as a pillar. In the Forum's Auckland Declaration (2004) the region's leaders stated: "We seek a Pacific region that is respected for the quality of its governance, the sustainable management of its resources, the full observance of democratic values, and for its defence and promotion of human rights" (PIF, 2004). The central presence of governance in the 2004 declaration and the resultant Pacific Plan of 2005 reflects the shifting geopolitical terrain of relations between Pacific island countries and their more powerful neighbors, as well as the heightened profile of governance in international development thinking and practice.

\section{The Forum and the Plan}

To continue our focus on the way that governance has been used in the Pacific, and to delineate the strong technocentric current at work in the taming of the concept as it is invoked by the Forum, we turn now to the crafting of the Plan itself. It is somewhat ironic that the very process whereby the Plan was finalized has been defended by the Forum as exemplifying good governance - they claimed to be broad-based and consultative - yet many critics have pointed out the lack of meaningful debate and the topdown nature of the process - indicating a serious deficit of good governance.

Under the Terms of Reference set out in Auckland in 2004, a Task Force ${ }^{8}$ was appointed and charged with "consult[ing] widely with Pacific Island countries and territories" and with other "stakeholders" "recognizing that a participatory, consultative and broad-based approach to national level consideration of regional integration is imperative in promoting ownership, which in turn will lead to commitment to implementation of the Pacific Plan" (PIF, 2005b, p. 4). The period between November 2004 and March 2005 was allocated for "Country and Stakeholder Consultations" (PIF, 2005b, p. 5), although, confusingly, it was

\footnotetext{
8 "The Task Force comprises senior officials from all Forum countries and members of the Council of Regional Organizations in the Pacific (CROP). The Secretary General of the PIF, who manages the Task Force, consults a Core Group of leaders, comprising the past, present and future Forum Chairs and a representative from the Smaller Island States." (PIF, 2005c)
}

also reported that "the Pacific Plan has been developed through an extensive 12-month period of broad-based consultations" (PIF, 2005b, p. 6), from mid-January 2005 until mid-September 2005. In any event, the Plan's architects were keen to represent the process as open and widely consultative. Secretary General Urwin told the participants at the New Zealand consultation that: "We therefore see the Plan as being the product of as wide a consultation process as we can achieve" (Urwin, 2005). The national consultations were organized in different ways, but typically involved "NGOs, civil society organization, faith-based organizations, youth, women's groups, professional associations, the private sector and the general population" (PIF, 2005 b, p. 6). Several (over 20) formal submissions resulted from the consultations, plus another 17 submissions were received from various organizations or consortia - altogether, a less than overwhelming response.

The compressed time-frame for the consultative process seriously undermined the PIF's claims of broad-based consultations (Rolfe, 2006, p. 92). The "desire for greater dialogue at all levels" was repeatedly emphasized by many during the consultation process (People's Forum, 2005, pp. 1-2). The Pacific Concerns Resource Centre (PCRC) listed all the problems its member groups had experienced in trying to assess the Plan and have input into its formulation. The PCRC statement was a comprehensive critique of the process, noting that the "realities of consultations" were such that:

- there was emphasis on the views of representatives of states rather than the wider community (including civil society organizations [CSOs]);

- the approach taken was one of asking for responses to "already prepared texts and concepts prepared by technocrats" - a "top-down process";

- the national consultations were typically one day events - too short a time to allow for the real discussion;

- participants involved in the consultations were generally not given enough time to study the draft Plan and "canvass the views of their own networks and constituencies";

- the document was not translated from English;

- consultations were held in urban centers only, effectively excluding rural or remote populations; and

- the consultations were not open or public "people's forums". PCRC (2005, p. 6)

The report of the New Zealand consultations also recorded that many participants were skeptical of the Plan's consultation process (among other things). They felt that it gave too much emphasis on government agencies and organizations and was more a "view from the capital cities" rather than an "authentic voice of Pacific people and communities" (New Zealand, 2005, p. 2). New Zealand participants echoed the observations that there was too little information about the Plan given out before the consultations and that the time frame was so short it did not allow for broad discussion (New Zealand, 2005, pp. 2-3). They 
insisted that drafts should have been translated into Pacific Island languages and that the English version should have used "plain English" instead of the technical, acronymfilled language employed (New Zealand, 2005, p. 6). Despite the presence of these criticisms, the draft Plan never was translated into the vernacular languages of island communities nor into "plain English" (People's Forum, 2005, p. 1).

\section{Tracing governance through the Plan}

\subsection{Defining governance}

Following the period of consultations, the Plan was finalized and endorsed in October 2005. While the Forum Secretariat has been at pains to stress that the Plan is a "living" document, this is belied by its appearance as a glossy printed document and, more importantly, by the way that it is evoked in the Pacific (PCRC, 2005). The Plan has become a channel through which aid and projects are funneled and it provides an important basis for understanding, imagining and monitoring the region. It is to the nature of governance as it was formulated and operationalized in this document that we now turn.

The Plan states its overall goal as being "to enhance and stimulate economic growth, sustainable development, good governance and security for Pacific countries through regionalism." The Plan has four objectives. Good governance, objective number three, is defined in the text as: "Improved transparency, accountability, equity and efficiency in the management and use of resources in the Pacific" (PIF, 2005a, p. 4) and in a footnote as "the transparent, accountable and equitable management of all resources." The footnote goes on to state: "Good governance is a prerequisite for sustainable development and economic growth" (PIF, 2005a, p. 4). Economic growth and sustainable development are objectives numbers one and two, respectively, of the Plan. Security is number four. In line with the contemporary governance agenda, good governance in the Plan is seen as a precondition for Pacific Island countries to have any chance of economic growth and sustainable development (see Goldsmith, 2005, for a critique). Sustainable development is defined in such a way that it is in a chicken and egg relation with economic growth. Economic growth is defined as "sustainable, pro-poor economic growth" (PIF, 2005a, p. 4) while sustainable development is defined as "the integration and mutual reinforcement of the three pillars of economic development, social development, and environmental conservation..." (PIF, 2005a, p. 4). Security, also, is positioned in a mutually constitutive relation with economic growth and sustainable development since it comprises the "stable and safe social (or human) and political conditions necessary for, and reflective of, good governance and sustainable development for the achievement of economic growth" (PIF, 2005a, p. 4). Thus security is also necessary for, as well as being reflective of, good governance meaning that all four objectives in the Plan are mutually co-generative in a virtuous-cycle of social change but with the catalyst role accorded to governance.

In its consideration of governance, the PIF deliberately eschewed alternative formulations, such as that offered by the United Nations. According to the UN, good governance is defined by eight attributes, the first two of which are that it be "participatory" and "consensus-oriented." Greenpeace, in its submission to the PIF, recommended that the Plan "should adopt the UN definition of good governance" (Greenpeace, 2005, p. 6) while UNIFEM Australia, among others, tackled the same issue in its submission, pointing out that "governance is not only political" but has "core human and social elements" that are excluded from the Plan's definition (UNIFEM Australia, 2005, p. 2; see also Pacific Youth Summit, 2005, p. 4).

Yet a narrow, technocratic definition of good governance was adopted very early on in the formulation of the Plan. In the Executive Summary of the Plan's Background Paper \#5 on Pacific Regionalism, for instance, governance is the first of the Plan's pillars to be discussed and is presented entirely in terms of economic management. Judging this to be the area of governance most likely to "yield high benefits" (PIF, 2005b, p. 35), Background Paper \#5 emphasizes four initiatives: "economic and statistical technical assistance" in areas such as macro-economics and tax policy; "assistance to customs officials" to collect revenue; a "regional ombudsman"; and a "regional panel of auditors" trained and operating to common standards. Clearly, the broad scope of issues and approaches capable of being deployed by the term governance was narrowed early on in the Plan's formulation.

Ironically, one aspect of this technocratic drift is the emphasis placed on institution building (offices of auditors, statisticians and so on) entailing the building up of the resources and surveillance capacities of the state, not their slimming down. This is regarded with suspicion not just by neoliberals, but by those who envision a much wider role for civil society in governance. Thus, for example, the Australian Council for International Development (ACFID) complains that the Plan's vision of governance entails strengthening the supplier institutions of good governance (as it were) within the state, rather than building and strengthening the role of civil society in more of a "demand-led governance" approach that it favors (ACFID, 2005, p. 10; see also Saldanha, 2004). Many of the national consultations reports and other submissions reflected such an acceptance of the overall governance agenda, while calling for a much more active role for civil society. The Solomon Islands Country Consultation Report, for example, noted that CSOs could be enrolled effectively in the governance project (Solomon Islands, 2005, p. 11; see also Australia, 2005, p. 4). This represents a willingness to embrace governance in a broader sense while criticizing its actual conceptualization in the plan. It leaves largely untouched, however, the fraught processes through which the CSO sector, or a subset of it, gets enrolled in the governance agenda (Watts, 1995). 
More critical responses have pointed out that giving a "role" to formally-organized and accredited CSOs may itself not be any guarantee of participation by ordinary people. While the Plan's repeated references to non-state actors, such as NGOs, might be taken as an acknowledgement of the significance of social actors other than the state, they also rely upon some level of institution-building and organizational capacity out of reach of 'communities' or even 'citizens'. Call of the Earth Llamado de la Tierra, for example, argues that the insistence on the mediating role of organizations (notably NGOs) is disempowering to ordinary Pacific citizens who have their own expertise, analyses and inter-generational interests to contribute within the governance domain (Call of the Earth Llamado de la Tierra, 2005, p. 3).

\subsection{Operationalizing governance}

The Plan is organized around the four objectives (economic growth, sustainable development, good governance, and security) and we can follow each of them, tracing their careers as they are defined and rendered into action plans and assessment measures. Our aim here is to see how the meaning of governance shifts in practice as its materiality is elaborated through implementation. Good governance is first detailed under the heading "Regional Priorities: For immediate implementation (2006-2008)" (PIF, 2005a, p. 6). Here, good governance has five components, a mix of specifics and abstractions (see Table 1), ranging from: institution building (in particular attorneys general, audit and ombudsman offices, judicial training and leadership codes); upgrade of regional statistical databases; ratification of international and regional human rights conventions and agreements; and regional support for the Forum Principles of Good Leadership and Accountability; to the extraordinarily ambitious priority of "enhancement of governance mechanisms, including in resource management; and in the harmonization of traditional and modern values and structures" (PIF, 2005a, p. 7). This is followed by a second tier, "Regional Priorities for Agreement in Principle" (PIF, 2005a, p. 8) and, lastly, by a set of "Regional Priorities for Further Analysis" (PIF, 2005a, p. 9). Each section adds detail to the Plan's conceptualization of good governance. The Plan then moves on to operationalize its objectives and priorities in two substantive attachments, each organized as a lengthy table. The first attachment concerns the Implementation Strategy for the first phase of the Plan (2006-2008) while the second provides a longer term (2006-2015) Monitoring and Evaluation Framework (PIF, 2005a, pp. 12-35) (see Table 1).

In elaborating the themes of good governance, the Plan emphasizes movement towards standardization (say of accounting or auditing) at the regional level, largely to converge with existing and emerging global standards. The Pacific region, though, has a huge variety of indigenous, colonial and hybrid traditions of governance which the Plan tends to treat very simplistically (as in the phrase "traditional and modern values and structures" (PIF, 2005a, p. 7)). Moreover, this variety is seen as a problem that must be overcome through "harmonization" (PIF, 2005a, p. 7). In shying away from the difficult and politically-loaded issues that would come from recognizing the variety of extant ways of doing governance in "managing and using resources" in the Pacific, the Plan ends up with a narrower, more instrumental and, ostensibly, de-politicized approach to governance. To be sure, this is a complex situation politically and perhaps the Forum is not an institution that can be expected to deal imaginatively with this issue as a whole. Even for the most technocratic and narrow goals associated with the standardization push, the historical geography of the region produces considerable challenges. For example, with some accounting and legal frameworks modeled on British systems, and others on French or American traditions, there will be considerable difficulties in tackling even the first of the "Initiatives for 2003-2006" under governance: the regional consolidation of audit offices. A national consultation in Palau noted the challenge: "Disparate audit systems can be equally valid, but they do not cross-over well for training or standardized legislation" (Republic of Palau, 2005, p. 6).

In tracing the path taken by the terms governance and good governance as they are defined and described in the Plan, it is evident there is a strange presence of equivocation and expansiveness in the governance narrative alongside a tendency towards narrowness. The term at once opens up possibilities (for participatory democracy for example) and closes them down (by focusing on building technical capacities and institutions like auditors for example). The Plan proceeds very quickly to the practical issues of implementation and assessment, which is where the governance agenda will be materially shaped. Therefore we now move to the Monitoring and Evaluation Framework laid out in the last section of the Plan (see Table 1).

\subsection{Monitoring governance}

Governance in the Plan is framed in such a way that its progress will be judged through indicators (see Macdonald, 1995, p. 22). In determining whether the Plan, or indeed a country, is performing, such indicators act to funnel aid and realize certain kinds of interventions. This reliance on indicators reduces the process of governing to what can be recognized quantitatively while the complex and diverse worlds of regulation, citizenship, violence, economy and identity are confined within an ordered rubric of alleged knowability. Indicators, as standardized quantitative scores, are the preferred technology of assessment under the governance agenda (Hacking, 1991; Dean, 1999; Punyaratabandhu, 2004). Indicators and performance measures are proliferating technologies, even as statisticians debate the trend and warn about quality, interpretation and application (Lievesley, 2001). The UNDP's "User's Guide" to governance indicators, for example, 
Table 1

Good governance in the Pacific Plan

\begin{tabular}{|c|c|c|c|c|c|}
\hline $\begin{array}{l}\text { Goal and objectives } \\
\text { strategic objective }\end{array}$ & $\begin{array}{l}\text { Regional priorities for immediate } \\
\text { implementation }\end{array}$ & $\begin{array}{l}\text { Regional priorities for } \\
\text { agreement in principle }\end{array}$ & $\begin{array}{l}\text { Regional priorities for further } \\
\text { analysis }\end{array}$ & $\begin{array}{l}\text { Implementation strategy } \\
(2006-2008)\end{array}$ & Monitoring and evaluation \\
\hline $\begin{array}{l}\text { Good governance } \\
\text { - Improved trans- } \\
\text { parency, } \\
\text { accountability, } \\
\text { equity and } \\
\text { efficiency in the } \\
\text { management of } \\
\text { resources in the } \\
\text { Pacific }\end{array}$ & $\begin{array}{l}\text { Good governance } \\
\text { - Regional support to consoli- } \\
\text { date commitments to key insti- } \\
\text { tutions such as audit and } \\
\text { ombudsman offices, leadership } \\
\text { codes, anti-corruption institu- } \\
\text { tions and departments of attor- } \\
\text { neys general; including through } \\
\text { judicial training and education } \\
\text { - Regional support to the Forum } \\
\text { Principles of Good Leadership } \\
\text { and Accountability } \\
\text { - Enhancement of governance } \\
\text { mechanisms, including in } \\
\text { resource management; and in } \\
\text { the harmonization of } \\
\text { traditional and modern } \\
\text { values and structures } \\
\text { - Upgrade and extension of } \\
\text { country and regional statistical } \\
\text { information systems and dat- } \\
\text { abases across all sectors } \\
\text { - Where appropriate, ratification } \\
\text { and implementation of interna- } \\
\text { tional and regional human } \\
\text { rights conventions, covenants } \\
\text { and agreements and support } \\
\text { for reporting and other } \\
\text { requirements }\end{array}$ & $\begin{array}{l}\text { Good governance } \\
\text { - Development of a strat- } \\
\text { egy to support participa- } \\
\text { tory democracy and } \\
\text { consultative decision- } \\
\text { making (including } \\
\text { NSAs, youth, women } \\
\text { and disabled), and elec- } \\
\text { toral process } \\
\text { - Development of com- } \\
\text { mon approaches to } \\
\text { financial regulation, } \\
\text { including through align- } \\
\text { ment of legislation and/ } \\
\text { or pursuit of common } \\
\text { prudential capacities }\end{array}$ & $\begin{array}{l}\text { Good governance } \\
\text { - Establishment of an account- } \\
\text { able and independent macro- } \\
\text { economic and micro-economic } \\
\text { technical assistance mechanism } \\
\text { (including statistics), to } \\
\text { strengthen treasury and finance } \\
\text { functions and provide eco- } \\
\text { nomic analysis }\end{array}$ & $\begin{array}{l}\text { Good governance } \\
\text { - Support or establish the regio- } \\
\text { nal consolidation of commit- } \\
\text { ments to key institutions such } \\
\text { as audit and ombudsman offi- } \\
\text { ces, customs, leadership codes, } \\
\text { anti-corruption institutions } \\
\text { and departments of attorneys } \\
\text { general; including through judi- } \\
\text { cial training and education } \\
\text { - Support the Forum Principles } \\
\text { of Good Leadership and } \\
\text { Accountability } \\
\text { - Enhance governance mecha- } \\
\text { nisms, including in resources } \\
\text { management, and in the har- } \\
\text { monization of traditional and } \\
\text { modern values and structures } \\
\text { - Upgrade and extend country } \\
\text { and regional statistical infor- } \\
\text { mation systems and databases } \\
\text { across all sectors } \\
\text { - Where appropriate, ratify and } \\
\text { implement international } \\
\text { and regional human rights } \\
\text { conventions, covenants and } \\
\text { agreements; and support for } \\
\text { reporting and other } \\
\text { requirements } \\
\text { - Develop a strategy to support } \\
\text { participatory democracy and } \\
\text { consultative decision-making } \\
\text { (including NSAs, youth, } \\
\text { women and disabled), and elec- } \\
\text { toral process } \\
\text { - Develop common approaches } \\
\text { to financial regulation, includ- } \\
\text { ing through alignment of legis- } \\
\text { lation and/or pursuit of } \\
\text { common prudential capacities } \\
\text { - Establish an accountable and } \\
\text { independent macro-economic } \\
\text { and micro-economic technical } \\
\text { assistance mechanism (includ- } \\
\text { ing statistics), to strengthen } \\
\text { treasury and finance functions } \\
\text { and provide economic analyses }\end{array}$ & $\begin{array}{l}\text { Good governance } \\
\text { - Increase (to be deter- } \\
\text { mined) in Voice and } \\
\text { Accountability indicator } \\
\text { - Increase (to be deter- } \\
\text { mined) in Political } \\
\text { Stability indicator } \\
\text { - Increase (to be deter- } \\
\text { mined) in Government } \\
\text { Effectiveness indicator } \\
\text { - Increase (to be deter- } \\
\text { mined) in Regulatory } \\
\text { Quality indicator } \\
\text { - Increase (to be deter- } \\
\text { mined) in Rule of Law } \\
\text { indicator } \\
\text { - Increase (to be deter- } \\
\text { mined) in Control of } \\
\text { Corruption (integrity) } \\
\text { indicator (for each } \\
\text { country) }\end{array}$ \\
\hline
\end{tabular}


describes 33 different indicators and refers to scores of other related measures (UNDP, 2004).

Six indicators are being tracked to assess the Plan's strategic objective of good governance (see Table 1). We take two of the six indicators to trace how governance gets operationalized in this crucial stage of the Plan: Voice and Accountability; and Regulatory Quality. These two indicators, like all six, are produced by the World Bank Institute. While the Plan contains provisions to build in Transparency International's data set for 14 Forum countries for indicator \#6, and the University of the South Pacific is developing an index that may be incorporated into the monitoring process (Duncan et al., 2004), for now, the World Bank's indicators are relied upon to assess the state of governance in the region.

The World Bank Institute's indicators are composites of many different sources. Thus, its Voice and Accountability indicator, designed to measure "political, civil and human rights," combines data from 19 different sources (PIF, 2005a, p. 33). In turn, each of those 19 sources provides data on one or more (up to 9) variables. For 207 countries World Bank analysts calculate a Voice and Accountability score in index form (with a range of -2.5 to +2.5 ) with a relative position based on the percentile rank of the index score. This permits cross-country comparisons and, if there is more than one year's data, some analysis of trends.

Even with so many potential data sources, the data set on Voice and Accountability for the PIF countries is astonishingly thin. Only Australia and New Zealand have more than the median number of data sources (eight) for this indicator (Kaufmann et al., 2005, p. 52). The median number of sources for all PIF countries in the World Bank's Voice and Accountability dataset is three. Two countries, the Cook Islands and Niue, are not in the data set at all, and three countries for which the index is calculated rely upon only two (Palau, The Marshall Islands and Nauru) ${ }^{9}$ (see Table 2).

The three sources of data that the World Bank relies upon most heavily in the calculations of this indicator for the PIF countries are: Freedom House's Freedom in the World database; the Cingranelli-Richards (CIRI) Human Rights Dataset; and Global Insight's World Markets Online database. Since these three are the most commonly used datasets for the PIF countries, we examine them to ascertain the type and quality of the data relied upon in measuring "voice and accountability" for Pacific countries.

Freedom House is a NGO based in the US and produces yearly "Freedom in the World" ratings, in which over 200 countries or territories are assigned scores for "Political

\footnotetext{
${ }^{9}$ There are several sources the World Bank uses for the Voice and Accountability indicator, but which do not cover PIF countries at all and are not included in Table 2. These are: Reporters Without Borders; Afrobarometer; United Nations Economic Commission for Africa; Freedom House, Countries at the Crossroads dataset; Freedom House, Nations in Transition dataset; Furnar; Latinobarometro; International Research \& Exchanges Board; and USAID/Vanderbilt University.
}

Rights" and "Civil Liberties," and on the basis of these are put into one of three categories (free, partly free, not free). To determine the ratings Freedom House researchers review "foreign and domestic news reports, academic analyses, non-governmental organizations, think tanks, individual professional contacts, and visits to the region" (Freedom House, 2005b: methodology section). They then write a country report upon which the ratings are based after review by a panel of regional experts. The PIF countries, however, appear to be the responsibility of the team's only Pacific Islands Analyst, a RAND Corporation political analyst (Freedom House, 2005b: survey team section).

The Cingranelli-Richards (CIRI) Human Rights Dataset is produced by two US academics - both political scientists. Their dataset is compiled from those of the US State Department's Country Reports on Human Rights Practices and Amnesty International's Annual Reports. The content of these reports is coded for 13 (disaggregated) variables (CIRI, 2005). Of these variables, the World Bank picks up four: those titled "Political Imprisonment," "Freedom of Movement," "Political Participation," and "Freedom of Speech and Press" for incorporation in its Voice and Accountability indicator. ${ }^{10}$

The third major source of data for the PIF countries is Global Insight which is a large economic forecasting company based in the US with offices worldwide - although it has no presence in any PIF member countries. It compiles a proprietary database called World Markets Online which assesses "institutional permanence" and "representativeness" (Kaufmann et al., 2003, p. 101).

The Regulatory Quality indicator deals explicitly with "market friendliness". The World Bank draws from 15 sources in compiling this indicator, each of which collates information on up to 18 variables. Like Voice and Accountability, the data associated with this indicator are thin for the Pacific (see Table 3). On average, the countries of the Pacific (excluding Australia and New Zealand and PNG) are covered by two different data sources. Three countries, Palau, Niue and Nauru, are not covered at all by any of the data sets, while the Cook Islands is covered by one and the Marshall Islands by two. The three data sets that dominate are Global Insight's World Markets Online database (see above) and the "Country Policy and Institutional Assessments" of the ADB and the World Bank. ${ }^{11}$

The "country policy and institutional assessments" (CPIAs) of the Asian Development Bank and the World

\footnotetext{
${ }^{10}$ The CIRI variables (of the total 13) that are not used in the Voice and Accountability indicator are: Political/Extrajudicial Killings - Unlawful/ Arbitrary Deprivation of Life; Disappearances; Torture; Freedom of Religion; Freedom of Assembly and Association; Worker Rights; Women's Political Rights; Women's Economic Rights; and Women's Social Rights (Cingranelli and Richards, 2004).

${ }^{11}$ Data sources included in the Regulatory Quality indicator but which do not cover PIF countries, and therefore are not included in Table 3, are: African Development Bank; United Nations Economic Commission for Africa; and European Bank for Reconstruction and Development.
} 
Table 2

Voice and Accountability

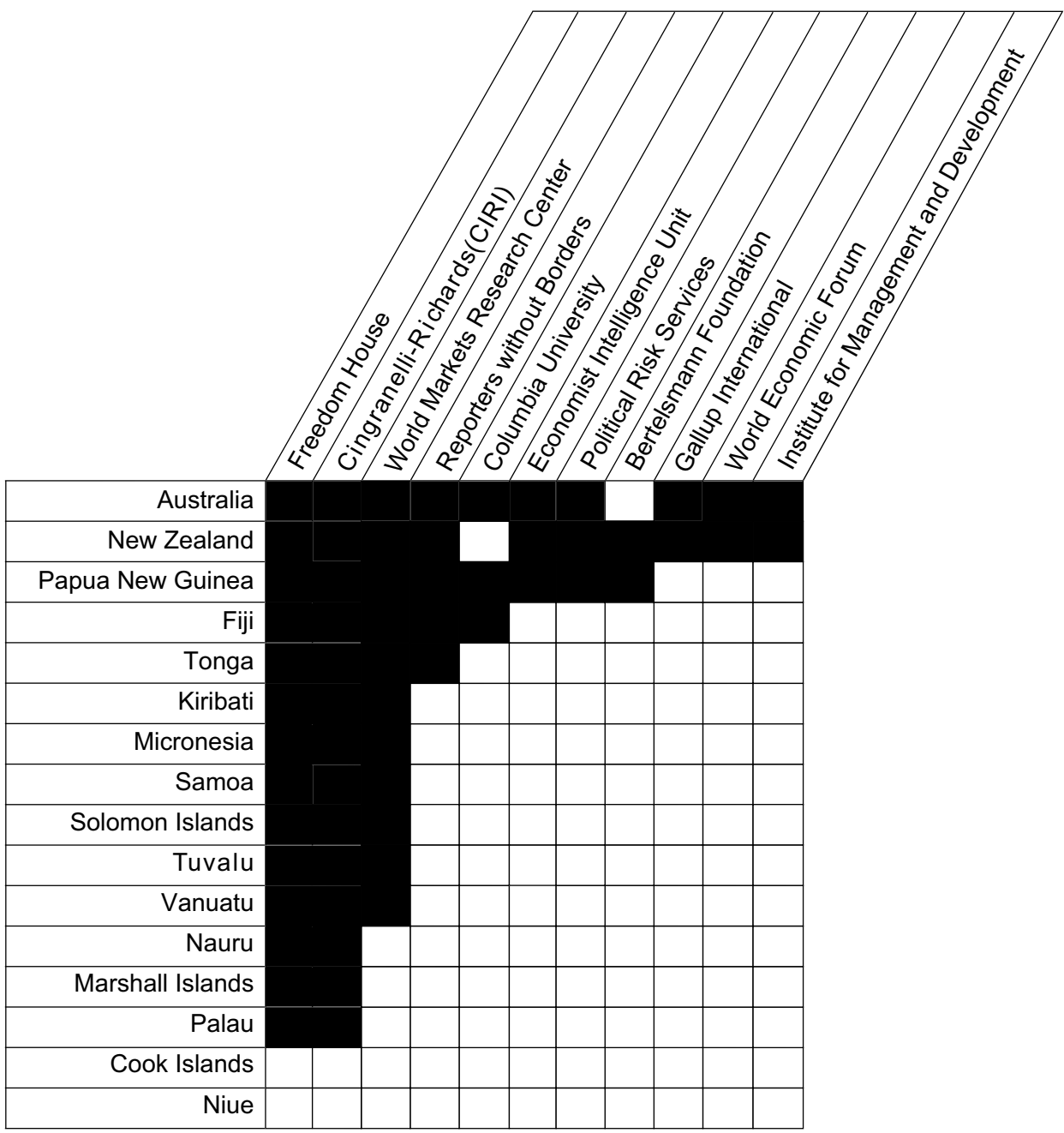

Bank are evaluations of borrower-country performance against a wide range of economic indicators. The World Bank's country assessment process emerged in the 1970s where it was used as a basis for its loans. The assessments, conducted annually on all borrowing governments, continue to provide the rationale for the World Bank's allocation of loans (Alexander, 2004). The World Bank now has four clusters associated with their country assessments that are weighted equally to provide an overall assessment: economic management; structural policies; policies for social inclusion and equity; and, public sector management. The criteria in the CPIA are heavily focused on small government, open markets, tariff reduction, privatization and private property rights (Powell, 2004).

For both indicators, Voice and Accountability and Regulatory Quality, the data could hardly be considered robust. Reliance upon such sketchy information seems at odds with the desire of the Plan's authors to assess gover- nance quantitatively. To take a concept as diffuse as governance and to be able to trim it and tame it so that it can be represented by a set of numbers is the guiding logic. Governance is thus evacuated of any 'unruly' content; turned into one variation of political risk analysis, a "calculative regime" of the sort long used by transnational capital (Miller, 1992; Herbert-Cheshire and Higgins, 2004). As expert knowledges about the Pacific are generated in the indicator industries of (predominantly US) universities, corporations and development organizations, the possibilities for Pacific islanders to define themselves are severely compromised.

The definitions and modes of monitoring governance provide a framework though which Pacific Island elites (English speaking, and with access to intergovernmental forums, officially-sanctioned civil society organizations or the upper echelons of government) are able to know and analyze their region, their economies and their potential 
Table 3

Regulatory Quality

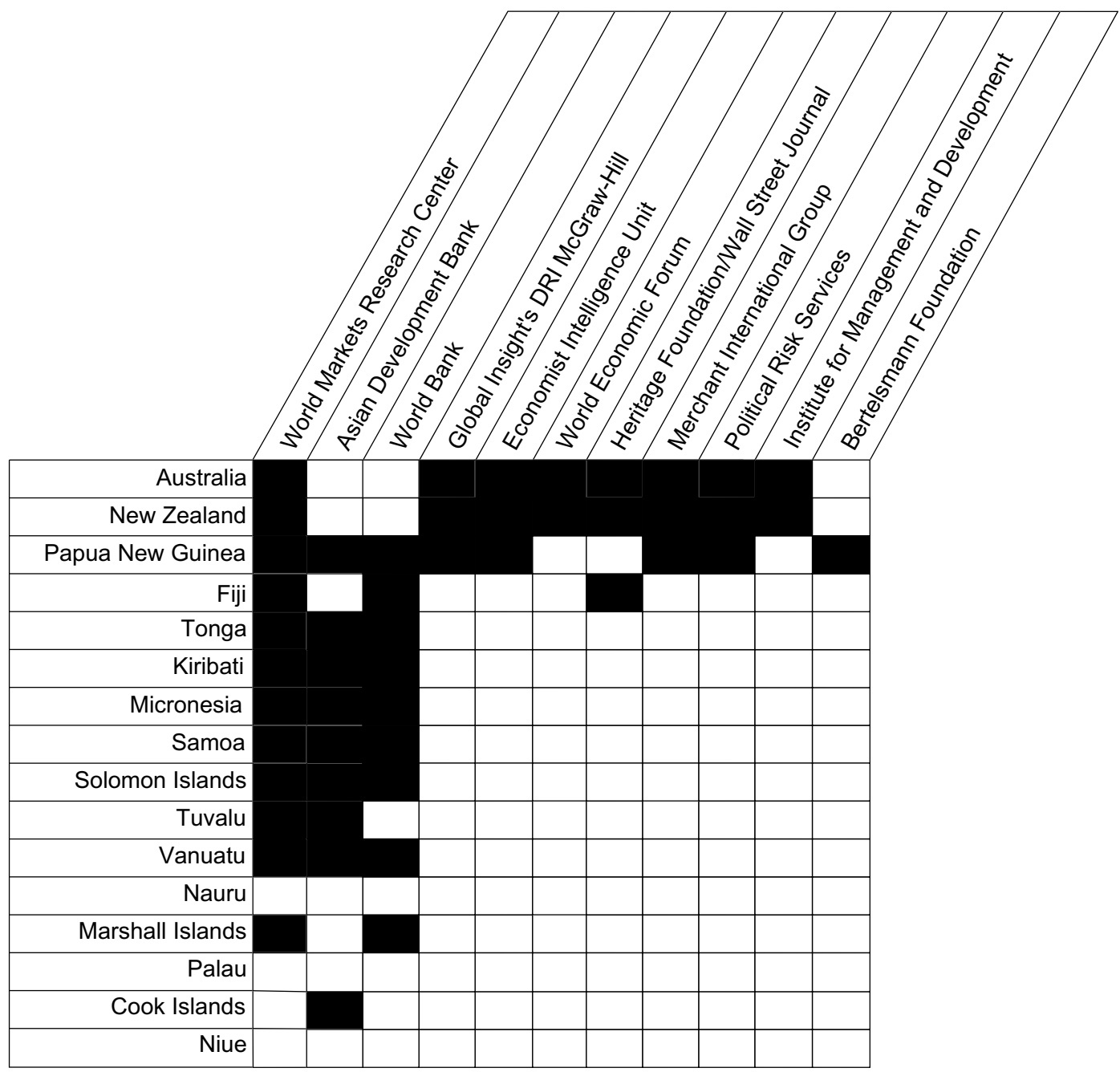

futures. Assessment by way of a set of thin, technocentric, neoliberal and securitized indicators leads to technocentric, neoliberal and securitized interventions. As the Pacific comes under the gaze of an expert calculus that frames forms of governing as 'good' or 'bad' the island nations and people are once again defined in terms of lack, with answers proffered by development experts from Australia, Japan and New Zealand and, further afield, the US and Europe.

Despite this comprehensive taming of governance, definitional ambivalence produced by an untamable discursive community allows, even invites, challenge. The Plan, while it was assembled in a top-down manner and operationalizes governance in technocratic ways, has been subject to a range of criticism and intervention, much of it centered on the issue of governance. We now describe some of the efforts underway in the Pacific to remake the Plan's formulation of governance and to open up political possibilities.

\section{Remaking governance}

While the concept of governance goes through a process of taming in the Pacific Plan and while intervention, aid and support from Ausaid and outside powers tend to empower a security-oriented and economistic interpretation of the word, a deeper and more critical investigation of the way governance is understood and deployed in the Pacific reveals such disciplining as at most partial and always incomplete. Continued use of the term governance by social movements, for example, does not sit easily with a deterministic reading. In theorizing the role of governance in the Pacific Plan, we were often struck by the closures associated with the term. Yet any tidy analyses were confronted by social-movement participants' capacity to retain broader participatory aspirations and to remake governance in entirely new ways. If good governance is so constraining, so colonized, why has it been deployed continuously in campaigns for gender and racial equality? 
This is in no sense a trivial point. Clearly, the Pacific Islands Forum, Ausaid, and the World Bank are not the only subjects making history in the Pacific. Rather, as the idea of governance is advanced, received, co-opted, rejected and contested by different agents, it is subject to struggles over meaning and implementation. This is not merely a matter of NGOs taking terms on offer and trying to interpret them in different ways. Neither does it imply that there are somehow separate and parallel versions of governance to be picked up and used. Rather, the term is brought into being and its meaning (re)configured as it is reworked in and through practice. In short, even as it is dedicated to reigning in CSOs and other social movement actors and ordinary citizens, the governance agenda itself is continually being re-made by these actors in the Pacific context.

The ways that different actors remake governance reflects the term's ambivalence (Fairclough, 1991). As a discourse, governance is unstable, heterogeneous and diffuse. Its meaning is neither uniform nor easily contained. Rather, it encloses a diverse field of meaning within which different and sometimes contradictory definitions are combined. An ambivalent discourse, in Fairclough's terms, is a combination of meanings (in contrast to an ambiguous one that is made up of one meaning or another). Governance, then, is a slippery discourse able simultaneously to tell different stories, to empower different interventions and to be reworked through surprisingly divergent practices.

The continual remaking of governance occurs in several ways as social movements act to make strategic use of the term within the context of the Pacific Plan and beyond it. For example, inasmuch as the Plan's indicators capture anything about concerns such as "political imprisonment" (as Voice and Accountability does) they could be useful for those wishing to pressure particular countries to improve their records on a specific issue like civil liberty. In such ways Pacific organizations are able to resist the powerful currents of the technocentric pull towards defining governance only in terms of security and market friendliness and retain a focus on more progressive meanings of the term (Interviews). Other efforts are geared more towards broadening the meaning of governance as laid out in the Plan particularly by injecting new items into the framework and stressing the importance of process. For example, several NGOs' submissions, including those from the People's Forum (2005), the Regional Rights Resource Team (2005) and UNIFEM Australia (2005), raised issues such as gender and freedom of information. To some extent, the presence of governance - particularly as it enters the Plan in its broader conception - reflects a success by social movements in getting issues such as corruption, human rights, women's issues, transparency and accountability onto the mainstream development agenda.

Unexpected opportunities emerge also from the uncontainability and ambivalence of the concept. Civil society groups are able to adeptly turn the concept upon those who deploy it so confidently. In particular, the concept is used to critique the Forum process itself. As discussed in
Section 4 above, the alliance of Pacific Regional NGOs, for example, has expressed deep concern about the consultative process associated with the Plan pointing out, among other criticisms, that the Plan was not translated into local languages, consultations were largely held in urban areas and timeframes associated with consultations were too short to allow for a democratic process. The civil society statement on the Pacific Plan, for example, called for Forum Leaders "Not to compromise transparency but ensure deeper and more meaningful dialogue and participatory processes" (PCRC, 2005, p. 6).

The unruliness of the concept of governance goes beyond the Pacific Plan and the Pacific Forum. Social movements use good governance to critique their own governments and to raise uncomfortable issues beyond those agreed by the Forum Leaders, including gender equality and the need for anti-discriminatory legal frameworks. Good governance can effectively act as a vehicle for demanding human rights and promoting participatory democracy. In this sense, NGOs can leverage the concept of governance to advance democracy beyond the scope of the Plan. For ACFID,

..the involvement of civil society will be important given the potential for the community to call for accountability on the part of government. (ACFID, 2005, p. 10)

The presence of governance as a legitimized issue within the region provides the opportunity for the exploration, articulation and practice of different forms of participatory democracy. This involves the suggestion of hybrid forms of governance that draw upon diverse situated processes (often referred to as traditional or local forms) that interpolate a technocentric/market friendly/security-oriented vision of governance as alternatives. A re-made concept of governance is suggested through the mapping of diverse visions that cross scale from the household, community, national and international level. One NGO worker, for example, sees the process of developing the Pacific Plan in terms of a missed opportunity for the exploration and development of forms of governance that spring from, and are appropriate to, Pacific peoples. She explains:

Since the Forum was established in 1971 this has been our argument: it could be a good opportunity for people to have a say in what's brought into an intergovernmental structure. (Interview)

One effort is taking place through the "gardening good governance and democracy" project of the Foundation of the Peoples of the South Pacific (FPSPI). The Foundation is a network of independent, secular NGOs in the Pacific that works to "foster self-reliance and sustainable development" (FPSPI, n.d.). The network's vision involves a regional approach that is based on an understanding of, and respect for, the diverse knowledges and experiences of $\mathrm{Pa}-$ cific Islands communities as well as an appreciation of resources and expertise of 'metropolitan' centers. In 
describing the "gardening good governance" project, the network elaborates, "The idea of nurturing and caring for a garden is applied to growing Pacific democracies so that like a productive and fruitful garden, Pacific democracies may produce vibrant civil societies and governing systems serving the needs and aspirations of Pacific peoples" (FPSPI, n.d.; see also Whyte et al., 2002).

\section{Conclusions}

We began by wondering whether the rapidly advancing governance agenda signals a closing down of the possibilities of politics. Indeed, in a direct reading of the Pacific Plan and the interventions it empowers there is ample evidence that governance (good and bad) is used as a disciplining technology. In reflecting on a wealth of research into the nature of the governance agenda (particularly urban governance) in Europe, Erik Swyngedouw (2005) concludes that the enrollment of civil society groups and corporations into "governance-beyond-the-state" while enacting a kind of inclusion, also serves to dissipate political relations so that notions of citizenship and democracy and claims based on them lose their efficacy. The case of the Pacific examined here, though ostensibly a world away from Europe, leads us to similar conclusions. It is clear that as the Pacific Plan works to build 'good governance' in the region it is offering important opportunities for civil society groups, but these are often circumscribed. The strong pull in the direction of a technocratic understanding of governance, together with the geopolitical vagaries that the Pacific Islands face, and the institutional nature of the PIF, lead to a double movement - enabled by the ambivalent nature of governance itself. Thus, even as the PIF's Pacific Plan pushes good governance in the Pacific in ways that might appear to open up political processes by including actors beyond the state, the technocratic language of inclusion, of civil society and stakeholders works to close down chances of challenging the bases for 'inclusion' and of enacting more radically inclusive visions of good governance (Kabeer, 2002). The Plan's operationalization of governance, from rushed consultations through to its assessment measures, acts to tame the unruly potentialities of governance, enforcing exclusions and recreating the region as in need of certain kinds of (neoliberal and securitized) intervention. Indeed, it is in its ability to pull together security and neoliberal agendas in a way that reinscribes the Pacific as deficient and in need of intervention that we find at once the most powerful, and pernicious, aspect of the term.

Yet the ambivalence of the term, its never-completelysettled definition, works to secure certain possibilities for groups dedicated to political change. While some activists and associated civil society groups press their agendas within a mainstream governance framework struggling to enroll a more progressive and expansive definition (based, for example, on human rights), others choose to work outside the institutional framework creating new visions and practices of governance. In refusing to be contained by a securitized, 'economically correct' and/or technocentric definition, Pacific-based groups enact a politics of governance at once situated and transformative.

Without doubt, people living in the Pacific region - especially the islands - face huge challenges in securing their livelihoods and their futures. The Pacific Plan, in its adoption of good governance as an objective, alongside economic growth, sustainable development, and security, did not take the opportunity to build on the region's particular history and geography, preferring to take up standard global models (of governance, of economic growth, and so on - see O'Neill et al., 2006) and apply them to the region. The Pacific Islands Forum's Plan is reshaping the region according to dominant development and geopolitical logics, yet a central tenet - governance - escapes the Plan. It is a term that seems at once to signal an attempt to close down political possibilities, yet permits some scope for the myriad of groups throughout the region seeking to enact more imaginative and participatory visions.

\section{Acknowledgements}

We gratefully acknowledge the research support of the Centre for Urban and Regional Studies at the University of Newcastle, Australia. The assistance of Centre staff Natalie Moore and Tanya Judd is deeply appreciated. The comments of colleagues in the School of Environmental and Life Sciences at the University of Newcastle, and from those who attended the panel at the IGU meeting in Brisbane where some of the ideas in this paper were presented, were very valuable. Thanks also to Katie Willis and the anonymous reviewers for their thoughtful comments.

\section{References}

Abrahamsen, R., 2000. Disciplining Democracy: Development Discourses and Good Governance in Africa. Zed Books, London.

Agence France Presse, 2006. Dire future for Pacific islands without economic growth. Agence France-Presse, 10 May.

Ahmed, I., 1999. Governance and the international development community: making sense of the Bangladesh experience. Contemporary South Asia 8 (3), 295-309.

Alexander, N., 2004. The World Bank as "Judge and Jury": The country policy and institutional assessment (CPIA) rating system and the PRSP. Citizens' Network on Essential Services (CNES). Accessed at: $<$ http://www.servicesforall.org/html/worldbank/judgeandjury.shtml $>$.

Asia Pulse, 2001. Australian PM reportedly snubs South Pacific Forum. Asia Pulse, 3 August.

Ausaid, 2006a. Summary of Australia's overseas aid program 2006-2007. Accessed at: < http://www.ausaid.gov.au/publications/pdf/summary_ 2006_2007.pdf>.

Ausaid, 2006b. Corruption Focus 21 (2), 11.

Australia, 2005. Australia National Consultation on Pacific Plan, Canberra. Accessed at: <http://www.pacificplan.org $>$.

Australian Council for International Development (ACFID), 2005. ACFID Pacific Working Group Comments on Working Draft of The Pacific Plan. Accessed at: <http://www.pacificplan.org $>$.

Baker, M., 2006. Australia's neo-colonialism is not helping its Pacific neighbours. The Age, 22 April. 
Barlow, K., 2006. Downer warns Pacific region is being left behind. Australian Broadcasting Corporation Transcripts, 11(May).

Brown, E., Cloke, J., 2004. Neoliberal reform, governance and corruption in the South: assessing the international anti-corruption crusade. Antipode 36 (2), 272-294.

Call of the Earth Llamado de la Tierra, 2005. The Pacific Plan: Culture, Trade and Intellectual Property Rights. Accessed at: <http:// www.pacificplan.org $>$.

Chin, J., 2003. Australian way at odds with Pacific Way. Canberra Times, 26 August.

Choudry, A., 2002. The Asian Development Bank -"Governing" the Pacific? ZNet, 6 June. Accessed at: <http://www.zmag.org/sustainers/ content/2002-06/06choudry.cfm>.

Cingranelli, D.L., Richards, D.L., 2004. The Cingranelli-Richards (CIRI) Human Rights Database Coder Manual.

CIRI, 2005. CIRI Human Rights Data Project. Accessed at: <http:// ciri.binghamton.edu/index.asp $>$.

Connell, J., 2006. Saving the Solomons: a new geopolitics in the 'Arc of Instability'? Geographical Research 44 (2), 111-122.

Courier Mail, 2004. Features: a closer watch on the Pacific Islands. The Courier-Mail, 10 August.

Davis, M., 2003. Pacific Islands Veto PM's Plan. Australian Financial Review, 15 August.

Dean, M., 1999. Governmentality: Power and Rule in Modern Society. Sage, London.

Department of Foreign Affairs and Trade (DFAT), n.d., a. Regional Assistance Mission to Solomon Islands: Operation Helpem Fren Accessed at: <www.dfat.gov.au/geo/solomon_islands/helpemfren/ intro.html >.

Department of Foreign Affairs and Trade (DFAT), n.d., b. Pacific Forum. Accessed at: <http://www.dfat.gov.au/geo/spacific/regional_orgs/spf. html $>$.

Doornbos, M., 2001. 'Good Governance': The rise and decline of a policy metaphor. The Journal of Development Studies 37 (6), 93 108.

Doran, S., 2004. Australia and the Origins of the Pacific Islands Forum Canberra: Commonwealth of Australia, Department of Foreign Affairs and Trade.

Doty, R.L., 1996. Imperial Encounters: The Politics of Representation in North-South Relations. University of Minnesota Press, Minneapolis.

Duffield, M.R., 2001. Global Governance and the New Wars: The Merging of Development and Security. Zed Books, London.

Duncan, R., Chand, S., 2002. The economics of the 'arc of instability'. Asian-Pacific Economic Literature 16, 1-9.

Duncan, R., Toatu, T., Gani, A., 2004. A conceptual framework for the development of a composite governance index for the Pacific Island Countries. Working Paper, August. Pacific Institute of Advanced Studies in Development and Governance Programme, University of the South Pacific.

Fairclough, N., 1991. What might we mean by 'Enterprise Discourse'? In: Keat, R., Abercrombie, N. (Eds.), Enterprise Culture. Routledge, London, pp. 38-57.

Fallah, A.B., 2006. Bad governance is Africa's major problem. The Forum (Monrovia, Liberia), 16 May. Accessed at: $<$ http://www.theperspective.org/forum/0516200603.html>.

Fickling, D., 2002. Australia navigates stormy Pacific waters. Guardian, 2 September.

Fine, B., 2002. Economics imperialism and the new development economics as Kuhnian paradigm shift? World Development 30 (12), $2057-2070$.

Foundation of the Peoples of the South Pacific International (FPSPI), n.d. Gardening good governance and democracy in the Pacific. Accessed at $<$ www.fspi.org.fj $>$.

Freedom House, 2005a. Map of Freedom. Accessed at: $<$ http://www. freedomhouse.org>

Freedom House, 2005b. Freedom in the World. Accessed at: $<$ http:// www.freedomhouse.. rg/template.cfm?page $=15 \&$ year $=2005>$.
Fry, G., 1997. Framing the islands: knowledge and power in changing Australian images of "the South Pacific". The Contemporary Pacific 9 (2), 305-339.

Fry, G., 2005. 'Pooled Regional Governance' in the Island Pacific: lessons from history. Pacific Economic Bulletin 20 (3), 111-119.

Gibson-Graham, J-K., 2006. A Postcapitalist Politics. University of Minnesota Press, Minneapolis.

Goldsmith, M., 2005. Theories of governance and Pacific microstates: the cautionary tale of Tuvalu. Asia Pacific Viewpoint 46 (2), 105-114.

Green, L., 2004. Bordering on the inconceivable: the Pacific solution, the migration zone and 'Australia's 9/11'. Australian Journal of Communication 31 (1), 19-36.

Greener-Barcham, B.K., Barcham, M., 2006. Terrorism in the South Pacific? Thinking critically about approaches to security in the region. Australian Journal of International Affairs 60 (1), 67-82.

Greenpeace, 2005. Submission on the Working Draft of the Pacific Plan. Accessed at: $<$ http://www.pacificplan.org $>$.

Grindle, M.S., 2002. Good enough governance: poverty reduction and reform in developing countries. JFK School, Harvard University Working paper. Accessed at: <http://www.grc-exchange.org/docs/ HD32.pdf>.

Grubel, J., 2003. Australian aid funds conditional on moves to fight corruption. 13 August. Accessed at: Australian Associated Press Financial News Wire.

Hacking, I., 1991. How should we do the history of statistics? In: Burchell, G., Gordon, C., Miller, P. (Eds.), The Foucault Effect: Studies in Governmentality. University of Chicago Press, Chicago, pp. 181196.

Harvey, C., 2004. Pacific islands 'a terrorist's paradise'. The Australian, 8 April. Accessed at: <http://www.freerepublic.com/focus/f-news/ $1115881 /$ posts $>$.

Henderson, J., 2003. The future of democracy in Melanesia: what role for outside powers? Asia Pacific Viewpoint 44 (3), 141-225.

Henningham, S., 1996. Australia and the Pacific Islands: the limits of influence. In: Klintworth, G. (Ed.), Asia-Pacific Security: Less Uncertainty, New Opportunities. St Martins Press, New York, pp. 148-159.

Herbert-Cheshire, L., Higgins, V., 2004. From risky to responsible: expert knowledge and the governing of community-led rural development. Journal of Rural Studies 20, 289-302.

Hewitt de Alcántara, C., 1998. Uses and abuses of the concept of governance. International Social Science Journal 50 (155), 105-113.

Hout, W., 2004. Political regimes and development assistance: the political economy of aid selectivity. Critical Asian Studies 36 (4), 591-613.

Howard, J., Dobell, G., 2004. Future terrorist attacks predicted from 'arc of instability.' Transcript from Radio Australia broadcast. 21/09/2004. Accessed at: <www.abc.net.au/ra/asiapac/programs/s1203291.htm>.

Huffer, E., 2005. Governance, corruption, and ethics in the Pacific. Contemporary Pacific 17 (1), 118-140.

Huffer, E., Molisa, G., 1999. Governance in Vanuatu. Pacific Economic Bulletin 14 (1), 101-112.

Huffer, E., So'o, A., 2005. Beyond governance in Samoa: understanding Samoan political thought. Contemporary Pacific 17 (2), 311-334.

Jayasuriya, K., Hewison, K., 2004. The antipolitics of good governance: from global social policy to a global populism? Critical Asian Studies 34 (3), 571-590.

Kabeer, N., 2002. Citizenship, affiliation and exclusion: perspectives from the South. IDS Bulletin 33 (2), 12-23.

Kaufmann, D., Kraay, A., Mastruzzi, M., 2003. Governance Research Indicators Project, Governance Matters III: Indicators for 1996-2002. Accessed at: $<$ http://www.worldbank.org/wbi/governance>.

Kaufmann, D., Kraay, A., Mastruzzi, M., 2005. Governance Research Indicators Project, Governance Matters IV: Indicators for 1996-2004. Accessed at: $<$ http://www.worldbank.org/wbi/governance $>$.

Kremmer, J., 2003. Bush visits his stalwart but parochial Aussie 'sheriff'; Australia's John Howard welcomes his US counterpart Wednesday, as the island nation focuses on its own backyard. The Christian Science Monitor 22 (October). 
Kyodo News, 2006. Joint Statement of Japan, Australia, and NZ for Pacific Island States. Kyodo News, 27 May. Accessed at: $<$ http:// asia.news.yahoo.com/060527/kyodo/d8hrr90o2.html >.

Larmour, P., 1997. Corruption and governance in the South Pacific. Pacific Studies 20 (3), 1-17.

Larmour, P., 2002. Conditionality, coercion and other forms of 'power': international financial institutions in the Pacific. Public Administration and Development 22, 249-260.

Leftwich, A., 1993. Governance, democracy and development in the Third World. Third World Quarterly 14 (3), 605-624.

Leftwich, A., 1994. Governance, the state, and the politics of development. Development and Change 25 (2), 363-386.

Leftwich, A., 2005. Politics in command: development studies and the rediscovery of social science. New Political Economy 10 (4), 573-607.

Lievesley, D., 2001. Making a difference: a role for the responsible international statistician? The Statistician 50 (4), 369-406.

Lilley, R., 2004. South Pacific leaders set to endorse reforms. Associated Press Newswires, 5 April.

Macdonald, B., 1995. Governance in Oceania. In: Governance and Good Government: Policy and Implementation in the South Pacific. National Centre for Development Studies, Canberra, pp. 21-27.

Miller, P., 1992. Accounting and objectivity: the invention of calculating selves and calculable spaces. Annals of Scholarship 9 (1/2), 61-86.

Mitchell, T., 2002. Rule of Experts: Egypt, Techno-Politics and Modernity. University of California Press, Berkeley.

Moore, M., 2002. Progressive realism: improving governance in the global South. Governance and Development Review (IDS). Accessed at: $<$ http://www.ids.ac.uk/gdr/position $\% 20$ papers/paper-03.pdf $>$.

Morgan, B., 2006. Technocratic v convivial accountability. In: Morgan, B. (Ed.), Public Accountability. Cambridge University Press, Cambridge, pp. 243-270.

Murray, W.E., Storey, D., 2003. Political conflict in postcolonial Oceania. Asia Pacific Viewpoint 44 (3), 213-224.

Nederveen-Pieterse, J., 2004. Globalization or Empire? Taylor and Francis, London.

New Zealand, 2005. The Pacific Plan: Brief Summary of New Zealand Public Consultations. Accessed at: $<$ http://www.pacificplan.org $>$.

O’Neill, P., Wright, S., Roberts, S., 2006. Competing views of the Pacific island economies. Paper presented at the International Geographical Union Congress, Brisbane.

Ong, A., 2006. Neoliberalism as Exception: Mutations in Citizenship and Sovereignty. Duke University Press, Durham, NC.

Pacific Concerns Resource Centre (PCRC), 2005. Civil Society Statement on Pacific Plan. Pacific News Bulletin, September.

Pacific Islands Forum (PIF), 1997. Forum Economic Action Plan. Forum Economic Ministers Meeting, 11 July.

Pacific Islands Forum (PIF), 2000a. Thirty-First Pacific Islands Forum, Communiqué. Accessed at: <http://www.dfat.gov.au/geo/spacific/ regional_orgs/pif31_communique.html $>$.

Pacific Islands Forum (PIF), 2000b. Biketawa Declaration. 31st Pacific Island Forum, Tarawa, Kiribati, 28 October.

Pacific Islands Forum (PIF), 2004. The Auckland Declaration. Pacific Islands Forum Special leaders' Retreat, Auckland, 6 April.

Pacific Islands Forum (PIF), 2005a. The Pacific Plan. Suva, Fiji, The Pacific Islands Forum Secretariat.

Pacific Islands Forum (PIF), 2005b. The Pacific Plan, Background Papers. Suva, Fiji, The Pacific Islands Forum Secretariat.

Pacific Islands Forum (PIF), 2005c. The Pacific Plan. Frequently Asked Questions. Accessed at: $<$ http://www.pacificplan.org $>$.

Pacific Youth Summit, 2005. Youth Statement on the Pacific Plan. Accessed at: <http://www.pacificplan.org $>$.

Pagden, A., 1998. The genesis of 'Governance' and enlightenment conceptions of the cosmopolitan world order. International Social Science Journal 50 (155), 7-15.

Payne, A., 1993. The politics of small state security in the Pacific. Journal of Commonwealth and Comparative Politics 31 (2), 103-132.
People's Forum, 2005. Proposals from The People's Forum: The NGO Consultation, 8.6.05. Accessed at: $<\mathrm{http}: / / \mathrm{www}$.pacificplan.org $>$.

Petersen, E., 2003. The catch in trading fishing access for foreign aid. Marine Policy 27 (3), 219-228.

Powell, J., 2004. The World Bank policy scorecard: The new conditionality? Update 43 Bretton Woods Project, 22 November. Accessed at: $<$ http://www.brettonwoodsproject.org/article.shtml?cmd $\% 5 \mathrm{~B} 126 \% 5 \mathrm{D}=$ $\mathrm{x}-126-84455>$.

Punyaratabandhu, S., 2004. Commitment to Good Governance, Development, and Poverty Reduction: Methodological Issues. Accessed at: <http://www.un.org/special-rep/ohrlls/ldc/Workshop/Monitoring\% $20 \operatorname{good} \%$ 20governance.pdf $>$.

Rajaram, P.K., 2003. Making place: The "Pacific Solution" and Australian emplacement in the Pacific and on refugee bodies. Singapore Journal of Tropical Geography 24 (3), 290-306.

Regional Rights Resource Team, 2005. Comments on Working Draft of The Pacific Plan for Strengthening Regional Cooperation and Integration. Accessed at: < http://www.pacificplan.org $>$.

Republic of Palau, 2005. Comments Regarding Regionalism for Consideration in the Development of the Pacific Plan. Accessed at: <http:// www.pacificplan.org $>$.

Rolfe, J., 2006. Beyond cooperation: towards an oceanic community. Australian Journal of International Affairs 60 (1), 83-101.

Rumley, D., Forbes, V.L., Griffin, C. (Eds.), 2006. Australia's Arc of Instability: The Political and Cultural Dynamics of Regional Security. Springer (GeoJournal Library), Dordrecht.

Saldanha, C., 2004. Strategies for good governance in the Pacific. AsianPacific Economic Literature 18 (2), 30-43.

Smith, N., 2005. The Endgame of Globalization. Routledge, New York.

Solomon Islands, 2005. Solomon Islands Country Consultation Report on the Pacific Plan. Accessed at: $<$ http://www.pacificplan.org $>$.

Sutherland, W., 2000. Global imperatives and economic reform in the Pacific Island States. Development and Change 31 (2), 459-480.

Swyngedouw, E., 2005. Governance innovation and the citizen: the Janus face of governance-beyond-the-State. Urban Studies 42 (11), 19912006.

Thomas, N., 1992. Colonial conversions: difference, hierarchy, and history in early twentieth-century evangelical propaganda. Comparative Studies in Society and History 34 (2), 366-389.

Thompson, M.R., 2004. Pacific Asia after 'Asian values': authoritarianism, democracy, and 'Good Governance'. Third World Quarterly 25 (6), 1079-1095.

UNIFEM Australia, 2005. UNIFEM Australia Urges Gender Equality for the Pacific Plan. Accessed at: <http://www.pacificplan.org $>$.

United Nations Development Programme (UNDP), 2004. Governance Indicators: A User's Guide. New York, UNDP. Accessed at: <http:// www.undp.org/oslocentre/docs04/UserGuide.pdf $>$.

United Nations Development Programme (UNDP), 2005. Governance for Livelihoods and Development in the Pacific. Accessed at: <http:// www.undp.org.fj/gold/>.

United Nations Economic and Social Commission for Asia and the Pacific., n.d. What is Good Governance? Accessed at: <http:// www.unescap.org/huset/gg/governance.htm>.

Urban, P., 2002. South Pacific Forum's Free Ride Must End. Australian Financial Review, 16 August.

Urwin, G., 2005. Pacific Plan Address by Secretary General Mr. Greg Urwin. 22-23 March, New Zealand National Consultations. Accessed at: $<$ http://www.pacificplan.org $>$.

Walker, D., Jones III, J.P., Roberts, S.M., Frohling, O., 2007. When participation meets empowerment: the WWF and the politics of invitation in the Chimalapas, Oaxaca. Annals Association of American Geographers 97 (2), 423-444.

Watts, M., 1995. A new deal in emotions. In: Crush, J. (Ed.), Power of Development. Routledge, New York, pp. 44-62.

Whyte, J., Vato, C., Kalontano, A., Siwatibau, S., 2002. Gardening Good Governance in Pacific Island Communities: Preliminary Insights from 
Vanuatu. Paper presented at DevNet 2002 conference, New Zealand. Accessed at: $<$ http://www.devnet.org.nz/conf2002/indexsession.html $>$.

Williams, R., 1985. Keywords: A Vocabulary of Culture and Society, Revised ed. Oxford University Press, New York.

Williams, D., Young, T., 1994. Governance, the World Bank and liberal theory. Political Studies 42 (1), 84-100.

Wolfowitz, P., 2006. Good Governance and Development: A Time for Action. Speech, Jakarta, Indonesia, 11 April. Accessed at: $<$ http:// web.worldbank.org >.

World Bank, 1989. Sub-Saharan Africa: From Crisis to Sustainable Growth. World Bank, Washington DC.
World Bank, 1993. Towards Higher Growth in the Pacific Island Economies: Lessons from the 1980s. World Bank, Washington DC.

World Bank, 2005a. Annual Report 2005, Regional Perspectives: East Asia and the Pacific. Accessed at: $<$ http://web.worldbank.org $>$.

World Bank, 2005b. Evaluation of World Bank Assistance to Pacific Member Countries, 1992-2002. Report No. 31940. World Bank, Washington DC.

Zanotti, L., 2005. Governmentalizing the post-cold war international regime: the UN debate on democratization and good governance. Alternatives 30 (4), 461-487. 